University of Nebraska - Lincoln

DigitalCommons@University of Nebraska - Lincoln

Faculty Papers and Publications in Animal

Science

Animal Science Department

2002

\title{
Effect of Corn Processing on Starch Digestion and Bacterial Crude Protein Flow in Finishing Cattle
}

\author{
R. J. Cooper \\ University of Nebraska-Lincoln \\ C. T. Milton \\ University of Nebraska-Lincoln \\ Terry J. Klopfenstein \\ University of Nebraska-Lincoln, tklopfenstein1@unl.edu \\ T. L. Scott \\ University of Nebraska-Lincoln \\ C. B. Wilson \\ University of Nebraska-Lincoln \\ See next page for additional authors
}

Follow this and additional works at: https://digitalcommons.unl.edu/animalscifacpub

Part of the Animal Sciences Commons

Cooper, R. J.; Milton, C. T.; Klopfenstein, Terry J.; Scott, T. L.; Wilson, C. B.; and Mass, R. A., "Effect of Corn Processing on Starch Digestion and Bacterial Crude Protein Flow in Finishing Cattle" (2002). Faculty Papers and Publications in Animal Science. 537.

https://digitalcommons.unl.edu/animalscifacpub/537

This Article is brought to you for free and open access by the Animal Science Department at DigitalCommons@University of Nebraska - Lincoln. It has been accepted for inclusion in Faculty Papers and Publications in Animal Science by an authorized administrator of DigitalCommons@University of Nebraska - Lincoln. 


\section{Authors}

R. J. Cooper, C. T. Milton, Terry J. Klopfenstein, T. L. Scott, C. B. Wilson, and R. A. Mass 


\title{
Effect of corn processing on starch digestion and bacterial crude protein flow in finishing cattle ${ }^{1}$
}

\author{
R. J. Cooper, C. T. Milton, T. J. Klopfenstein ${ }^{2}$, T. L. Scott, C. B. Wilson, and R. A. Mass \\ Department of Animal Science, University of Nebraska, Lincoln 68583-0908
}

\begin{abstract}
Six ruminally and duodenally cannulated yearling steers $(523 \mathrm{~kg})$ were used in a replicated $3 \times 3$ Latin square design experiment to study the effects of corn processing on nutrient digestion, bacterial $\mathrm{CP}$ production, and ruminal fermentation. Dietary treatments consisted of $90 \%$ concentrate diets that were based on dry-rolled (DRC), high-moisture (HMC), or steam-flaked (SFC) corn. Each diet contained 2.0\% urea (DM basis) as the sole source of supplemental nitrogen. Each period lasted $17 \mathrm{~d}$, with d 1 through 14 for diet adaptation and $d 15$ through 17 for fecal, duodenal, and ruminal sampling. Dry matter and OM intakes were similar for DRC and SFC but were approximately $15 \%$ higher $(P<0.05)$ for HMC. True ruminal OM digestibilities were 18 and $10 \%$ greater $(P<0.05)$ for HMC than for DRC or SFC, respectively. Ruminal starch digest-
\end{abstract}

ibilities were similar between HMC and SFC and were approximately $19 \%$ greater $(P<0.05)$ than DRC. Postruminal $\mathrm{OM}$ digestibility was similar among treatments; however, postruminal starch digestibility was $15 \%$ greater $(P<0.05)$ for SFC than for DRC or HMC, which were similar. Total-tract $\mathrm{DM}$ and $\mathrm{OM}$ digestibilities were similar between HMC and SFC and were $4 \%$ greater $(P<0.05)$ than DRC. Likewise, total-tract starch digestibilities were similar between HMC and SFC and were $3 \%$ greater $(P<0.05)$ than DRC. Bacterial $\mathrm{CP}$ flow to the duodenum was $29 \%$ greater $(P<0.05)$ for HMC than for DRC or SFC, which were similar. Bacterial $\mathrm{N}$ efficiencies were similar among treatments. Based on bacterial CP flow from the rumen, we estimate that dietary DIP requirements are approximately $12 \%$ higher for HMC-based diets than for DRC or SFC-based diets, which were similar.

Key Words: Bacterial Proteins, Cattle, Maize, Starch Digestion

(C)2002 American Society of Animal Science. All rights reserved.

J. Anim. Sci. 2002. 80:797-804

\section{Introduction}

Starch is the primary energy component of corn and therefore is the primary nutrient in typical finishing diets used to promote high levels of production. Thus, optimal starch utilization is fundamental to improving the efficiency of feedlot cattle production (Theurer, 1986). The primary goal of corn processing for feedlot diets is to increase energy (starch) availability (Owens et al., 1997). In a survey of six feedlot consultants responsible for the nutrition program for approximately 3.6 million cattle, Galyean (1996) reported that all corn was processed before feeding, most commonly by steam flaking, followed by dry-rolling and high-moisture storage.

Huntington (1997) summarized data from 14 trials published from 1986 through 1995 on the influence of

\footnotetext{
${ }^{1}$ Published with the approval of the director as paper no. 13193, journal series, Nebraska Agric. Res. Div.

${ }^{2}$ Correspondence: C220 Animal Sciences (phone: 402-472-6443; fax: 402-472-6362; E-mail: tklopfenstein1@unl.edu).

Received March 12, 2001.

Accepted September 26, 2001.
}

corn processing on starch digestibility. For dry-rolled, high-moisture, and steam-flaked corn, ruminal starch digestibilities were 76.2, 89.9, and $84.8 \%$ of intake, respectively. Postruminal starch digestibilities were 68.9, 67.8 , and $92.6 \%$ of that entering the duodenum, respectively, whereas total-tract starch digestibilities were $92.2,95.3$, and $98.9 \%$ of intake, respectively.

Increasing ruminally available energy (starch) should increase the synthesis and efficiency of bacterial CP $(\mathbf{B C P})$ in the rumen and therefore increase the dietary degradable intake protein (DIP) requirement (NRC, 1996). Our objectives were 1) to evaluate the effect of corn processing on site and extent of starch digestion, 2) to evaluate the effect of corn processing on BCP production, and 3) predict dietary DIP requirements for steers fed dry-rolled, high-moisture, and steam-flaked corn-based diets based on BCP production.

\section{Materials and Methods}

Animals and Diets. Six crossbred yearling steers (523 $\mathrm{kg}$ ) were used in a replicated $3 \times 3$ Latin square design experiment to study the effects of corn processing on 
Table 1. Composition of experimental diets (\% of DM)

\begin{tabular}{lccc}
\hline \hline & & Diet $^{\mathrm{a}}$ & SFC \\
\cline { 2 - 4 } Ingredient & DRC & HMC & - \\
\hline Dry-rolled corn & 81.75 & - & - \\
High-moisture corn & - & 81.75 & 81.75 \\
Steam-flaked corn & - & - & 5.0 \\
Alfalfa hay & 5.0 & 5.0 & 5.0 \\
Cottonseed hulls & 5.0 & 3.0 & 3.0 \\
Molasses & 3.0 & 5.25 & 5.25 \\
Dry supplement & 5.25 & 2.00 & 2.00 \\
Urea & 2.00 & 1.59 & 1.59 \\
Limestone & 1.59 & 0.81 & 0.81 \\
Finely ground corn & 0.81 & 0.81 & 0.81 \\
Finely ground corn & 0.81 & 0.30 & 0.30 \\
Salt & 0.30 & 0.25 & 0.25 \\
Chromium oxide & 0.25 & 0.12 & 0.12 \\
Potassium chloride & 0.12 & 0.10 & 0.10 \\
Tallow & 0.10 & 0.05 & 0.05 \\
Trace mineral premix & 0.05 & 0.02 & 0.02 \\
Rumensin premix & 0.02 & 0.01 & 0.01 \\
Tylan premix & 0.01 & 0.01 & 0.01 \\
Vitamin premix & 0.01 & 0.001 & 0.001 \\
Ammonium sulfate & 0.001 &
\end{tabular}

${ }^{\mathrm{a} D R C}=$ dry-rolled corn, $\mathrm{HMC}$ = high-moisture corn, $\mathrm{SFC}=$ steam-flaked corn.

${ }^{\mathrm{b}}$ All diets supplemented to contain a minimum of $0.7 \% \mathrm{Ca}, 0.28 \% \mathrm{P}, 0.6 \% \mathrm{~K}$, and $0.15 \% \mathrm{~S}$. All diets contained $30 \mathrm{mg} / \mathrm{kg}$ monensin and $11 \mathrm{mg} / \mathrm{kg}$ tylosin (Elanco Animal Health, Indianapolis, IN).

nutrient digestion, protein production, and ruminal fermentation. Dietary treatments (Table 1) consisted of $90 \%$ concentrate diets that were based on dry-rolled (DRC), high-moisture (HMC), or steam-flaked (SFC) corn. Each diet contained $2.0 \%$ urea (DM basis) as the sole source of supplemental nitrogen so that ruminal ammonia would not limit ruminal fermentation or microbial protein synthesis. In addition, all diets were supplemented to contain a minimum of $0.7 \% \mathrm{Ca}, 0.28 \%$ $\mathrm{P}, 0.6 \% \mathrm{~K}$, and $0.15 \% \mathrm{~S}$. All diets contained $30 \mathrm{mg} / \mathrm{kg}$ monensin (Elanco Animal Health, Indianapolis, IN), $11 \mathrm{mg} / \mathrm{kg}$ tylosin (Elanco Animal Health), and 0.25\% chromium oxide as an external marker.

Dry-rolled corn was processed to a mean particle size (Ensor et al., 1970) of 2,850 $\pm 4 \mu \mathrm{m}$ through a singlestack rollermill. Kernels visually appeared to be broken into thirds. High-moisture corn was harvested at approximately $29 \%$ moisture, processed through a roller mill, and stored in a covered concrete bunker for approximately $250 \mathrm{~d}$. Mean particle size (Ensor et al., 1970) of high-moisture corn was $722 \pm 10 \mu \mathrm{m}$, and soluble protein (Waldo and Goering, 1979) was $46 \%$ at the time of feeding. Steam-flaked corn was processed to a flake density of $0.37 \mathrm{~kg} / \mathrm{L}$ ( $29 \mathrm{lb} / \mathrm{bushel})$ at a commercial feedlot (Hi-Gain Feedlot, Inc., Cozad, NE) and delivered to the research feedlot on a weekly basis. Mean particle size (Ensor et al., 1970) was 2,278 $\pm 6 \mu$ at the time of feeding. Corn for processing methods was not from single hybrid but rather a blend of commercial yellow dent hybrids commonly grown in Nebraska and found in commodity corn.

Ruminal and double-L duodenal cannulas (Streeter et al., 1991) were surgically placed in each steer approx- imately 1 yr before the trial began. Surgical and postsurgical care procedures were similar to those outlined by Stock et al. (1991), and all procedures had been reviewed and accepted by the University of Nebraska Institutional Animal Care Program. Steers were housed in 1.5- $\times 2.4-\mathrm{m}$ individual slotted-floor pens in a $25^{\circ} \mathrm{C}$ temperature-controlled room. Steers were fed for ad libitum intake once daily at 0900 .

Sampling. Each 17-d period consisted of a 14-d diet adaptation and a $3-d$ sample collection. Duodenal and fecal grab samples were collected eight times daily at 3 -h intervals, with collections performed $1 \mathrm{~h}$ later each day so that samples were obtained for each 1-h interval of a day. For each steer in each period, fecal samples were composited on an equal wet-weight basis, dried in a $60^{\circ} \mathrm{C}$ oven, and ground to pass through a $1-\mathrm{mm}$ screen. Duodenal samples were freeze-dried, ground to pass through a 1-mm screen, and composited for each steer in each period on an equal dry-weight basis.

On d 16 of each period, ruminal fluid samples were collected every $3 \mathrm{~h}$ starting at 0900 using the suction strainer technique (Raun and Burroughs, 1962). Ruminal fluid samples $(50 \mathrm{~mL})$ were immediately measured for $\mathrm{pH}$ using a combination electrode and then frozen $\left(-20^{\circ} \mathrm{C}\right)$ for further analysis.

At the end of each period, whole-ruminal contents (2 $\mathrm{kg}$ ) were collected from each steer at $0800 \mathrm{~h}$. Microbial activity was stopped by mixing ruminal contents with $1 \mathrm{~L}$ of cold, 3.7\% formalin solution $(9 \mathrm{~g} \mathrm{NaCl}$ and 100 $\mathrm{mL}$ of $37 \%$ formaldehyde/ $\mathrm{L}$ ) and then freezing at $-20^{\circ} \mathrm{C}$. Thawed samples were then blended at $1,000 \times g$ for 1 min and then strained through two layers of cheesecloth. Samples were then composited within each di- 
etary treatment on an equal fluid-volume basis. Composited samples were then centrifuged to isolate ruminal bacteria following the procedures of Bock et al. (1991).

At the end of the experiment, steers were maintained on their respective diets from the third period of the Latin square (two steers on each diet) in order to measure in situ rate of protein and starch digestion. Composites of DRC, HMC, and SFC from Periods 1, 2, and 3 were freeze-dried and weighed into Dacron bags $(5 \times$ $10 \mathrm{~cm}, 53-\mu \mathrm{m}$ pore size; Ankom, Fairport, NY; $5 \mathrm{~g} / \mathrm{bag}$ ). Dacron bags were incubated in the rumen for $0,12,24$, and $96 \mathrm{~h}$ (five bags/corn processing type/time point/ steer). All bags were removed from steers at the same time, rinsed, and dried at $60^{\circ} \mathrm{C}$ for $48 \mathrm{~h}$. Bags were then composited within corn type, time point, and steer. Composited samples were ground to pass through a 1mm screen.

Laboratory Analysis and Calculations. Feed ingredient and orts samples were analyzed for DM throughout the trial in a $60^{\circ} \mathrm{C}$ oven for $48 \mathrm{~h}$. Laboratory DM of feed ingredient, orts, duodenal, fecal, bacteria, and in situ samples was determined in a $100^{\circ} \mathrm{C}$ oven for $12 \mathrm{~h}$, and organic matter was determined by ashing samples at $500^{\circ} \mathrm{C}$ for $12 \mathrm{~h}$ (AOAC, 1995). Nitrogen content of feed ingredient, orts, duodenal, bacteria, and in situ samples was determined using a nitrogen analyzer (AOAC, 1995). Chromium concentration of feed ingredient, orts, duodenal, and fecal samples was determined using atomic absorption (Williams et al., 1962). Starch content of feed ingredient, orts, duodenal, fecal, and in situ samples was determined by procedures of Murphy et al. (1994). Purine content of duodenal and bacteria samples was determined using a modified procedure of Zinn and Owens (1986) as described by Creighton et al. (2000). Ruminal fluid VFA concentration was measured using the procedures of Erwin et al. (1961), and $\mathrm{NH}_{3}$ $\mathrm{N}$ was measured using the procedures of McCullough (1967).

Microbial OM and CP flowing to the duodenum was calculated using purines as the microbial marker (Zinn and Owens, 1986). Organic matter fermented in the rumen was calculated as $\mathrm{OM}$ intake minus total $\mathrm{OM}$ reaching the duodenum corrected for microbial OM reaching the duodenum. Microbial OM was assumed to be equal to microbial $\mathrm{N} \div 0.0996$ (Clark et al., 1992). Microbial DM was assumed to contain $21 \%$ starch (NRC, 1996) in order to calculate true ruminal starch digestibilities.

In situ rates of ruminal starch and protein disappearance were calculated assuming first-order kinetics (Mertens, 1987). Washed, but not incubated, bags were used for zero time points. Nitrogen and starch remaining in the 96-h samples were considered to be extent of digestion and the rate of digestion (kd) of the potentially digestible fraction was determined. To estimate DIP and ruminal starch digestibility values for each processed corn type, a corn ruminal passage rate (kp) of $3.44 \% / \mathrm{h}$ was assumed, which was the average corn rate of passage in steers fed $90 \%$-concentrate DRCbased diets as reported by Shain et al. (1999). Corn DIP (\% of $\mathrm{CP})$ was calculated as follows: $100-[\mathrm{CP} \times(\{[\mathrm{kp} /$ $(\mathrm{kp}+\mathrm{kd})] \times \mathrm{B}\}+96$-h indigestible $\mathrm{CP})]$, where $\mathrm{CP}=$ crude protein content of corn and $\mathrm{B}=$ potentially degradable fraction. Likewise, corn ruminal starch digestion $(\%)$ was calculated as: $100-(\{[\mathrm{kp} /(\mathrm{kp}+\mathrm{kd})] \times \mathrm{B}\}$ + 96-h indigestible starch).

Statistical analysis. Data were analyzed as a replicated $3 \times 3$ Latin square design using the mixed procedure of SAS (SAS Inst. Inc., Cary, NC). Steer within period was the experimental unit. Model consisted of steer, period, and dietary treatment. Steer within period was a random effect. Least squares means were separated using the least significance difference method when a significant $(P<0.10) F$-test was detected.

Ruminal ammonia, ruminal $\mathrm{pH}$, and VFA data were analyzed as repeated measures using the GLM procedure of SAS. Steer within period was the experimental unit. Model consisted of steer, period, and dietary treatment. Time of the eight observations within a day was the repeated variable. Least squares means were separated using the least significance difference method when a significant $(P<0.10) F$-test was detected.

In situ data were analyzed as a randomized complete block design using the mixed procedure of SAS. Steer was the experimental unit. Model consisted of grain processing method, base diet, and the processing method $\times$ base diet interaction. Least squares means were separated using the least significance difference method when a significant $(P<0.10) F$-test was detected.

\section{Results}

Influence of corn processing on intake and characteristics of ruminal and total-tract digestion are shown in Table 2. Dry matter and OM intakes were $15 \%$ greater $(P<0.05)$ for HMC than for DRC or SFC, which were similar. Starch intakes were similar $(P>0.10)$ among treatments.

True ruminal OM digestibilities were approximately 18 and $10 \%$ greater $(P<0.05)$ for HMC compared with DRC and SFC, respectively. True ruminal starch digestibilities were similar between HMC and SFC and were approximately $18 \%$ higher $(P<0.05)$ compared with DRC. Postruminal OM digestibility was similar among treatments; however, postruminal starch digestibility was $15 \%$ greater $(P<0.05)$ for SFC compared with DRC and HMC, which were similar. Total-tract $\mathrm{DM}$ and $\mathrm{OM}$ digestibilities were similar between HMC and SFC and were $4 \%$ greater $(P<0.05)$ than DRC. Likewise, total-tract starch digestibilities were similar between HMC and SFC and were $3 \%$ greater $(P<0.05)$ than DRC.

Bacterial CP flow to the duodenum was $29 \%$ greater $(P<0.05)$ for HMC compared with DRC and SFC, which were similar. Bacterial $\mathrm{N}$ efficiencies were similar 
Table 2. Influence of corn processing on characteristics of ruminal and total-tract digestion

\begin{tabular}{|c|c|c|c|c|}
\hline \multirow[b]{2}{*}{ Item } & \multicolumn{3}{|c|}{ Treatment $^{\mathrm{a}}$} & \multirow[b]{2}{*}{ SEM } \\
\hline & $\mathrm{DRC}$ & HMC & $\mathrm{SFC}$ & \\
\hline \multicolumn{5}{|l|}{ Intake, kg/d } \\
\hline DM & $12.7^{\mathrm{b}}$ & $14.5^{\mathrm{c}}$ & $12.5^{\mathrm{b}}$ & 0.4 \\
\hline $\mathrm{N}$ & $0.313^{\mathrm{b}}$ & $0.375^{\mathrm{c}}$ & $0.308^{\mathrm{b}}$ & 0.013 \\
\hline $\mathrm{OM}$ & $12.1^{\mathrm{b}}$ & $13.8^{\mathrm{c}}$ & $11.9^{\mathrm{b}}$ & 0.5 \\
\hline Starch & 7.8 & 8.4 & 7.5 & 0.3 \\
\hline \multicolumn{5}{|l|}{ Ruminal digestibility, $\%$} \\
\hline Apparent OM & $52.5^{\mathrm{b}}$ & $62.9^{\mathrm{c}}$ & $57.3^{\mathrm{bc}}$ & 2.4 \\
\hline \multicolumn{5}{|l|}{ True OM } \\
\hline 0.2 purine: $\mathrm{N}^{\mathrm{d}}$ & $70.3^{\mathrm{b}}$ & $82.5^{\mathrm{c}}$ & $75.3^{\mathrm{b}}$ & 1.6 \\
\hline 0.3 purine: $\mathrm{N}^{\mathrm{e}}$ & $64.4^{\mathrm{b}}$ & $76.0^{\mathrm{c}}$ & $69.3^{\mathrm{b}}$ & 1.8 \\
\hline Apparent starch & $76.2^{\mathrm{b}}$ & $91.7^{\mathrm{c}}$ & $89.6^{\mathrm{c}}$ & 1.6 \\
\hline \multicolumn{5}{|l|}{ True starch } \\
\hline 0.2 purine: $\mathrm{N}^{\mathrm{d}}$ & $83.8^{\mathrm{b}}$ & $100.2^{\mathrm{c}}$ & $97.2^{\mathrm{c}}$ & 1.2 \\
\hline 0.3 purine: $\mathrm{N}^{\mathrm{e}}$ & $81.2^{\mathrm{b}}$ & $97.3^{\mathrm{c}}$ & $94.7^{\mathrm{c}}$ & 1.3 \\
\hline \multicolumn{5}{|c|}{ Postruminal digestibility, $\%$ entering } \\
\hline $\mathrm{OM}$ & 69.1 & 67.1 & 72.5 & 1.8 \\
\hline Starch & $84.4^{\mathrm{b}}$ & $86.5^{\mathrm{b}}$ & $98.3^{\mathrm{c}}$ & 2.1 \\
\hline \multicolumn{5}{|l|}{ Total-tract digestibility, $\%$} \\
\hline DM & $83.5^{\mathrm{b}}$ & $86.7^{\mathrm{c}}$ & $87.2^{\mathrm{c}}$ & 0.7 \\
\hline $\mathrm{OM}$ & $84.6^{\mathrm{b}}$ & $88.0^{\mathrm{c}}$ & $88.1^{\mathrm{c}}$ & 0.7 \\
\hline Starch & $96.1^{b}$ & $98.7^{\mathrm{c}}$ & $99.8^{\mathrm{c}}$ & 0.5 \\
\hline Nitrogen flow to duodenum, g/d & 234 & 262 & 274 & 18 \\
\hline \multicolumn{5}{|l|}{ Bacterial $\mathrm{N}$ flow to duodenum, $\mathrm{g} / \mathrm{d}$} \\
\hline 0.2 purine: $\mathrm{N}^{\mathrm{d}}$ & $208^{\mathrm{f}}$ & $271^{\mathrm{g}}$ & $211^{\mathrm{f}}$ & 18 \\
\hline 0.3 purine: $\mathrm{N}^{\mathrm{e}}$ & $138^{\mathrm{f}}$ & $180^{\mathrm{g}}$ & $140^{\mathrm{f}}$ & 12 \\
\hline \multicolumn{5}{|c|}{ Bacterial $\mathrm{N}$ efficiency, $\mathrm{g}$ of $\mathrm{N} / \mathrm{kg}$ OM truly degraded in rumen ${ }^{\mathrm{d}}$} \\
\hline 0.2 purine: $\mathrm{N}^{\mathrm{d}}$ & 25.4 & 23.7 & 23.9 & 1.7 \\
\hline 0.3 purine: $\mathrm{N}^{\mathrm{e}}$ & 18.5 & 17.2 & 17.4 & 1.4 \\
\hline
\end{tabular}

${ }^{\text {a DRC }}=$ dry-rolled corn; HMC = high-moisture corn; and SFC = steam-flaked corn.

${ }^{\mathrm{b}, \mathrm{c}}$ Means in row with unlike superscripts differ $(P<0.05)$.

${ }^{\mathrm{d}}$ Calculated using measured purine: $\mathrm{N}$ ratio of 0.2 .

${ }^{\mathrm{e}}$ Calculated using assumed purine: $\mathrm{N}$ ratio of 0.3 .

f,g Means in row with unlike superscripts differ $(P<0.10)$.

among treatments. We measured a bacterial purine: $\mathrm{N}$ ratio of 0.2 from our rumen samples. However, we feel that this ratio is incorrect because it provided bacterial $\mathrm{N}$ flows that were greater than total $\mathrm{N}$ flow from the duodenum (Table 2). Furthermore, overestimation of bacterial flow from the rumen resulted in extremely high true ruminal starch digestibilities, over $100 \%$ for HMC (Table 2). A recent report (Obispo and Dehority, 1999) argues that purine: $\mathrm{N}$ ratios determined using differential centrifugation often underestimate the purine: $\mathrm{N}$ ratio and, thus, overestimate $\mathrm{BCP}$ flows from the rumen. Similar to our data, they measured a purine: $\mathrm{N}$ ratio of 0.2 using differential centrifugation on mixed rumen contents; however, they measured a purine: $\mathrm{N}$ ratio of 0.55 using pure bacterial cultures. Based on their findings and other observations within our lab (data not shown), we decided to recalculate the data using an assumed purine:N ratio of 0.3 . Values for both purine: $\mathrm{N}$ ratios are shown in Table 2. Relative differences among treatments were similar; however, we feel that the purine: $\mathrm{N}$ ratio of 0.3 provided more realistic bacterial $\mathrm{N}$ flows, true ruminal starch digestibilities, and bacterial $\mathrm{N}$ efficiencies.
Effects of corn processing on in situ protein and starch digestion characteristics are shown in Table 3. Crude protein content was higher for HMC than for DRC or SFC. Rate of ruminal protein digestion was approximately $217 \%$ more rapid $(P<0.05)$ for HMC compared with the average of DRC and SFC, which were similar. As a result, the DIP value was approximately $137 \%$ higher $(P<0.05)$ for HMC compared with the average of DRC and SFC. Rate of ruminal starch digestion was similar between HMC and SFC, and approximately $58 \%$ greater $(P<0.05)$ than DRC. Ruminal starch digestibilities were similar between HMC and SFC and were $31 \%$ greater $(P<0.05)$ than DRC.

Effects of corn processing on ruminal fermentation characteristics are shown in Figures 1 through 6. All rumen fermentation characteristics measured, except for butyrate, had significant $(P<0.01)$ time $\times$ corn processing method interactions.

\section{Discussion}

A primary goal in corn processing is to increase starch availability. Our in vivo data suggest that early-harvest 
Table 3. Effect of corn processing on in situ protein and starch digestion

\begin{tabular}{lcccc}
\hline \hline & \multicolumn{3}{c}{ Treatment } \\
\cline { 2 - 4 } & DRC & HMC & SFC & SEM \\
\hline Crude protein, \% of DM & 9.0 & 9.9 & 9.1 & - \\
Rate of protein digestion, \%/h & $3.12^{\mathrm{b}}$ & $10.54^{\mathrm{c}}$ & $3.52^{\mathrm{b}}$ & 0.52 \\
96-h extent of protein digestion, \% & $65.7^{\mathrm{bc}}$ & $83.1^{\mathrm{b}}$ & $53.6^{\mathrm{c}}$ & 8.6 \\
Undegradable intake protein, \% of $\mathrm{DM}^{\mathrm{e}}$ & $6.20^{\mathrm{b}}$ & $3.26^{\mathrm{c}}$ & $6.78^{\mathrm{b}}$ & 0.25 \\
Undegradable intake protein, \% of CP & 68.9 & 32.9 & 74.5 & - \\
Degradable intake protein, \% of CP & 31.1 & 67.1 & 25.5 & - \\
Starch content, \% of DM & 74.0 & 71.0 & 73.0 & - \\
Rate of starch digestion, \%/h & $2.97^{\mathrm{b}}$ & $4.8^{\mathrm{c}}$ & $4.39^{\mathrm{c}}$ & 0.47 \\
96-h extent of strach digestion, \% & $84.0^{\mathrm{b}}$ & $91.7^{\mathrm{c}}$ & $98.5^{\mathrm{d}}$ & 1.4 \\
Ruminal starch digestion, \% & $52.0^{\mathrm{b}}$ & $68.4^{\mathrm{c}}$ & $67.7^{\mathrm{c}}$ & 1.4 \\
\hline
\end{tabular}

${ }^{\text {a DRC }}=$ dry-rolled corn; HMC = high-moisture corn; $\mathrm{SFC}=$ steam-flaked corn

b,c,d Means in row with unlike superscripts differ $(P<0.05)$.

${ }^{\mathrm{e}}$ Assumes rate of ruminal passage of $3.44 \% / \mathrm{h}$ for corn.

high-moisture corn processing and storage or steam flaking corn to $0.37 \mathrm{~kg} / \mathrm{L}(29 \mathrm{lb} / \mathrm{bu})$ increases ruminal starch digestion by $19 \%$ over dry rolling. In situ data suggest that HMC and SFC have $33 \%$ greater ruminal starch digestibilities than DRC. The in vivo and in situ data have similar trends, but the in situ ruminal starch digestibilities are approximately 22 percentage units lower than in vivo values. Differences are probably due to corn particle size. In the in situ procedure, processed corn placed in the bags was similar in particle size and integrity as it would be going into the feed bunk, unlike the in vivo processed corn, which was masticated as the animal consumed the diet. Other data from our lab suggest that mastication increases the in situ DIP value of DRC by approximately 8 percentage units, and HMC

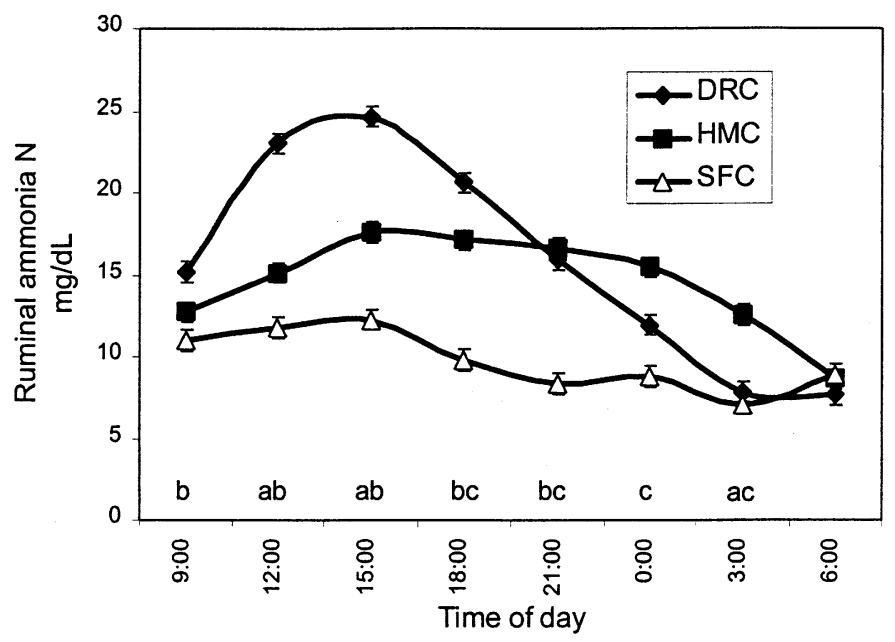

Figure 1. Effect of corn processing on ruminal ammonia concentration. Steers were fed at 0900 . Treatment $\times$ time interaction $(P<0.01)$. Differences among means within a sampling time are denoted by letters on the $\mathrm{x}$-axis and the following footnotes. ${ }^{a}$ Dry rolled corn (DRC) vs high moisture corn $(\mathrm{HMC})(P<0.10)$. ${ }^{\mathrm{b}} \mathrm{DRC}$ vs steam flaked corn $(\mathrm{SFC})(P<0.10)$. ${ }^{\mathrm{C}} \mathrm{HMC}$ vs SFC $(P<0.10)$. by approximately 9 percentage units (data not shown). We do not have data for starch digestion, but we would hypothesize similar trends.

We measured apparent ruminal starch digestibilities of 76, 92, and 90\% for DRC, HMC, and SFC, respectively. Huntington (1997) summarized data from 14 trials published from 1986 through 1995 and reported average ruminal starch digestibilities of 76,90 , and $85 \%$ for DRC, HMC, and SFC, respectively. Galyean et al. (1976), the only published data that the authors are aware of that directly compare starch digestibilities of DRC, HMC, and SFC-based diets in a single trial, reported ruminal starch digestibilities of 78,89 , and $83 \%$, respectively. We found that SFC had $18 \%$ greater $(P<$ $0.05)$ ruminal starch digestibility compared with DRC,

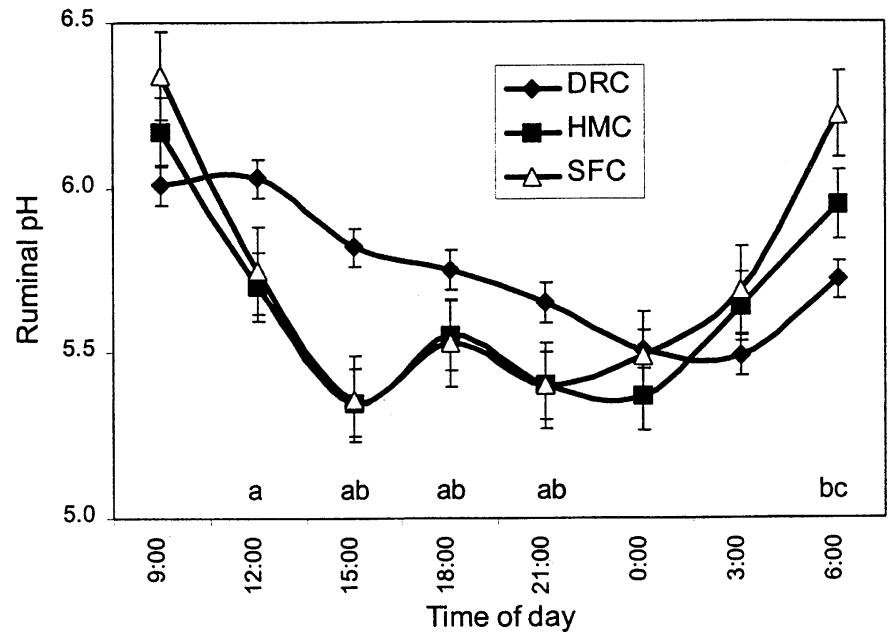

Figure 2. Effect of corn processing on ruminal $\mathrm{pH}$. Steers were fed at 0900 . Treatment $\times$ time interaction $(P$ $<0.01)$. Differences among means within a sampling time are denoted by letters on the $\mathrm{x}$-axis and the following footnotes. ${ }^{a}$ Dry rolled corn (DRC) vs high moisture corn $(\mathrm{HMC})(P<0.10) .{ }^{\mathrm{b}} \mathrm{DRC}$ vs steam flaked corn $(\mathrm{SFC})(P<$ $0.10)$. ${ }^{~} H i g h$ moisture corn $(\mathrm{HMC})$ vs SFC $(P<0.10)$. 


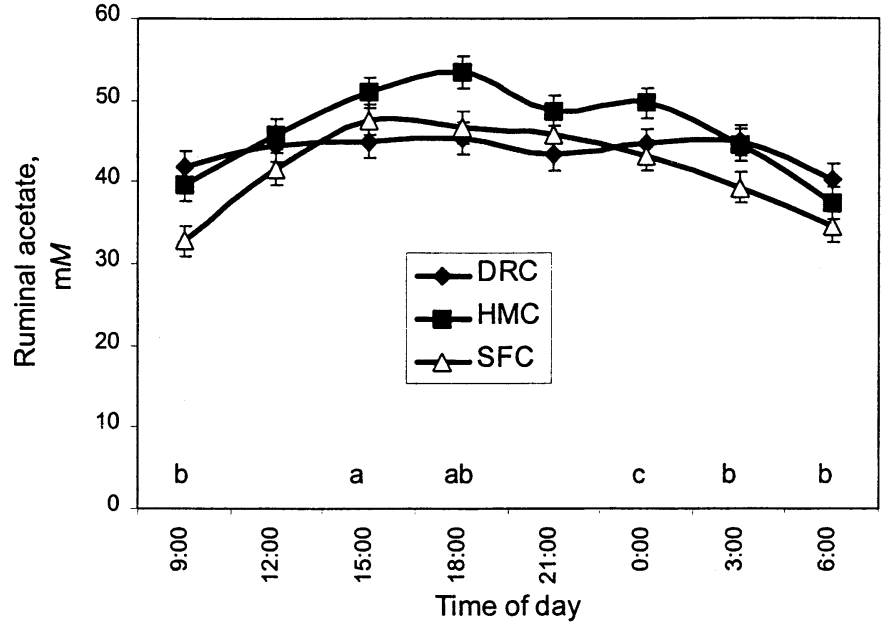

Figure 3. Effect of corn processing on ruminal acetate concentration. Steers were fed at 0900 . Treatment $\times$ time interaction $(P<0.01)$. Differences among means within a sampling time are denoted by letters on the $\mathrm{x}$-axis and

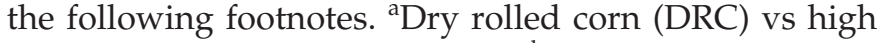
moisture corn $(\mathrm{HMC})(P<0.10)$. ${ }^{\mathrm{b}} \mathrm{DRC}$ vs steam flaked corn (SFC) $(P<0.10)$. ${ }^{c}$ High moisture corn $(\mathrm{HMC})$ vs SFC $(P<0.10)$.

whereas Huntington (1997) and Galyean et al. (1976) reported values of 12 and 6\%, respectively.

We measured $15 \%$ greater $(P<0.05)$ postruminal starch digestibilities with SFC compared with DRC and HMC, which were similar. Huntington (1997) reported that SFC had approximately $35 \%$ greater postruminal starch digestibilities than the average of DRC and

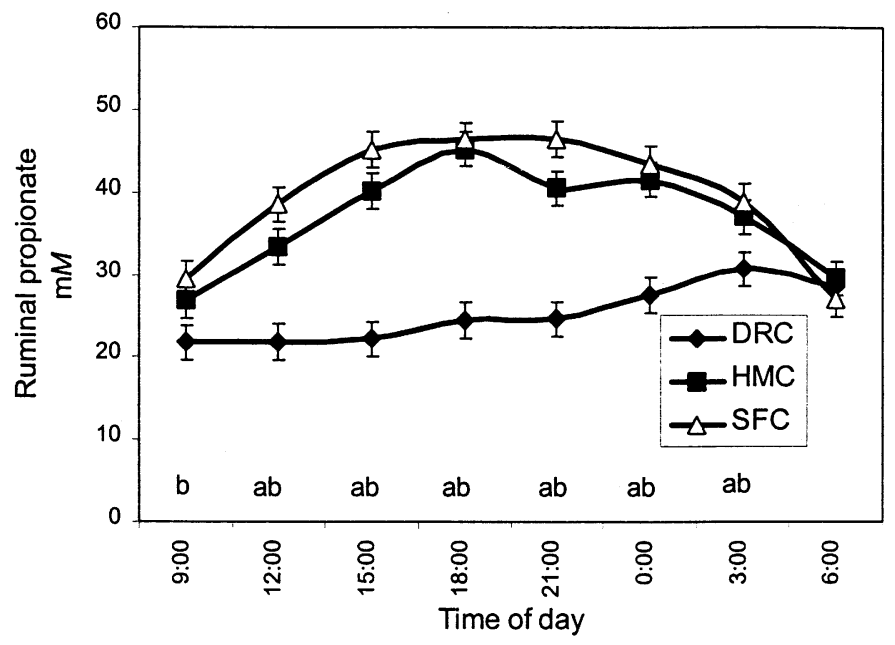

Figure 4. Effect of corn processing on ruminal propionate concentration. Steers were fed at 0900 . Treatment $x$ time interaction $(P<0.01)$. Differences among means within a sampling time are denoted by letters on the $\mathrm{x}$ axis and the following footnotes. ${ }^{a}$ Dry rolled corn (DRC) vs high moisture corn $(\mathrm{HMC})(P<0.10) .{ }^{\mathrm{b}} \mathrm{DRC}$ vs steam flaked corn $(\mathrm{SFC})(P<0.10)$.

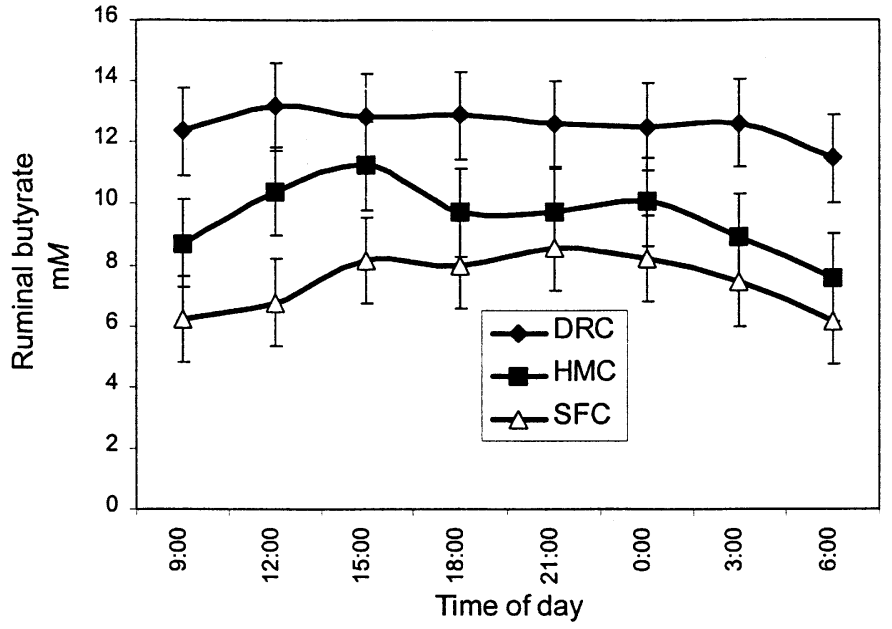

Figure 5. Effect of corn processing on ruminal butyrate concentration. Steers were fed at 0900 . Treatment $\times$ time interaction $(P=0.53)$; dry rolled corn $(\mathrm{DRC})$ vs steam flaked corn $(\mathrm{SFC})(P<0.05)$.

HMC, which were similar. Galyean et al. (1976) did not find significant differences in postruminal starch digestion among processing methods, but HMC and SFC were numerically 7 and $11 \%$, respectively, greater than DRC. Greater postruminal starch digestion for SFC compared with DRC might be due to simply less starch entering the duodenum for SFC. However, our data suggest that postruminal digestion is also greater for SFC than HMC, even though HMC had numerically less starch flowing from the rumen.

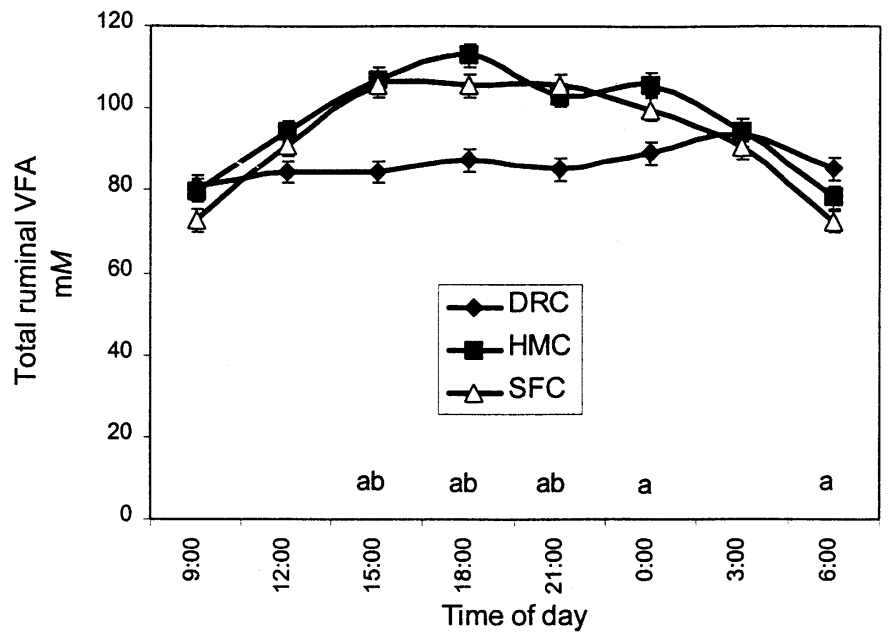

Figure 6. Effect of corn processing on total ruminal VFA concentration. Steers were fed at 0900 . Treatment $x$ time interaction $(P<0.01)$. Differences among means within a sampling time are denoted by letters on the $\mathrm{x}$ -

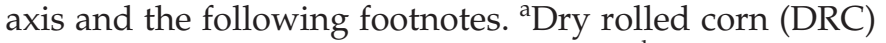
vs high moisture corn $(\mathrm{HMC})(P<0.10) .{ }^{\mathrm{b}} \mathrm{DRC}$ vs steam flaked corn $(\mathrm{SFC})(P<0.10)$. 
We measured 3\% lower $(P<0.05)$ total-tract starch digestibility with DRC compared with the average of HMC and SFC, which were similar. Huntington (1997) reported a 7\% lower total-tract starch digestibility for DRC compared with SFC, with HMC being intermediate. Similar to our data, Galyean et al. (1976) reported $3 \%$ lower total-tract starch digestion for DRC compared with HMC and SFC, which were similar.

Our results suggest that $\mathrm{BCP}$ flow to the duodenum is similar between cattle consuming DRC and SFCbased diets, even though ruminal OM and starch digestibilities were greater for SFC. Bacterial CP flow for HMC was 29\% greater than the average of DRC and SFC. Bacterial CP efficiencies were statistically similar among treatments; therefore, differences in BCP flow are due to differences in intake and ruminal digestibility of OM (primarily starch in these diets). Few data are available that have measured the BCP flow in cattle fed HMC-based diets. However, several trials have been published, primarily from one laboratory, which compare DRC and SFC. Reported BCP flows range from similar (Zinn et al., 1995), to 13\% greater (Barajas and Zinn, 1998), 28\% greater (Zinn, 1990), and 31\% greater (Zinn et al., 1998) for steers fed SFC compared with DRC-based diets. Bacterial CP efficiencies were similar between SFC and DRC in all of these trials except Zinn et al. (1995), which reported a $14.2 \%$ lower BCP efficiency for SFC compared with DRC. In our trial, steers fed SFC had greater $(P<0.05)$ ruminal OM degradation compared with $\mathrm{DRC}$, but the bacterial $\mathrm{N}$ efficiency was numerically $6 \%$ lower resulting in equal BCP flow from the rumen. The lower ruminal $\mathrm{pH}$ values observed for steers fed HMC and SFC (Figure 2) likely caused the numerical reductions in bacterial $\mathrm{N}$ efficiency compared with DRC (Strobel and Russell, 1986; NRC, 1996).

Ruminal ammonia concentrations (Figure 1) were well above levels suggested to be necessary to maintain maximum BCP production $(5.0 \mathrm{mg} / \mathrm{dL}$; Satter and Slyter, 1974). Trends in ruminal ammonia concentration agree with the net effect of corn DIP, ruminal starch digestibility, and BCP flow. The DRC and SFC diets have approximately the same dietary DIP; however, ruminal ammonia is much lower for SFC due to greater ruminal starch fermentation. Additionally, even though BCP flow was greater for HMC compared with SFC, ruminal ammonia concentrations were much greater for HMC because of the greater concentration of DIP in HMC compared with SFC.

Bacterial CP flow data allow us to predict relative differences in dietary DIP requirement for DRC, HMC, and SFC-based diets. Level 1 of the NRC (1996) model suggests that dietary DIP requirements are equal to $\mathrm{BCP}$ flow to the duodenum ( $\mathrm{g} / \mathrm{d}$ basis). This assumes that at the point the DIP requirement is met, the loss of ammonia from the rumen as a result of flowing to the duodenum and absorption through the rumen wall is equal to the amount of recycled N. Given this assumption, dietary DIP requirements for steers consuming DRC, HMC, and SFC-based diets would be $0.87,1.13$, and $0.88 \mathrm{~kg} / \mathrm{d}$, respectively. Dividing by DM intake, these values convert to DIP requirements of 6.9, 7.8, and $7.0 \%$ of dietary DM for DRC, HMC, and SFC-based diets, respectively. These DIP requirements cannot be considered absolute because we used an assumed purine: $\mathrm{N}$ ratio to calculate $\mathrm{BCP}$ flow; however, they can be used to determine relative differences among corn processing methods. Therefore, based on BCP flow from the rumen, our HMC-based diet required approximately $12 \%$ more dietary DIP than DRC or SFC-based diets, which were similar.

\section{Implications}

Bacterial CP flow to the duodenum is related to ruminal OM digestibility and, thus, is increased by corn processing methods, which increase the rate and extent of ruminal OM fermentation. Greater bacterial CP flow for diets based on high-moisture corn suggests higher dietary degradable intake protein requirements compared with diets based on dry-rolled and steam-flaked corn. Degradable intake protein deficiencies may decrease metabolizable protein supply to the animal and energy yield from ruminal starch fermentation.

\section{Literature Cited}

AOAC. 1995. Official Methods of Analysis. 14th ed. Association of Official Analytical Chemists, Arlington, VA.

Barajas, R., and R. A. Zinn. 1998. The feeding value of dry-rolled and steam flaked corn in finishing diets for feedlot cattle: influence of protein supplementation. J. Anim. Sci. 76:1744-1752.

Bock, B. J., D. L. Harmon, R. T. Brandt, Jr., and J. E. Schneider. 1991. Fat source and calcium level effects on finishing steer performance digestion and metabolism. J. Anim. Sci. 69:22112224.

Clark, J. H., T. H. Klusmeyer, and M. R. Cameron. 1992. Microbial protein synthesis and flows of nitrogen fractions to the duodenum of dairy cows. J. Dairy Sci. 75:2304-2323.

Creighton, K. W., R. A. Mass, and T. J. Klopfenstein. 2000. Modifications of the purine assay to increase accuracy and precision. J. Anim. Sci. 78(Suppl. 1):121 (Abstr.).

Ensor, W. L., H. H. Olson, and V. F. Colenvander. 1970. A report: Committee on classification on particle size in feedstuffs. J. Dairy Sci. 53:689-690.

Erwin, E. S., D. J. Marco, E. M. Emery. 1961. Volatile fatty acid analysis of blood and rumen fluid by gas chromatography. J. Dairy Sci. 44:1768-1770.

Galyean, M. L. 1996. Protein levels in beef cattle finishing diets: industry application, niversity research, and systems results. J. Anim. Sci. 74:2860-2870.

Galyean, M. L., D. G. Wagner, and R. R. Johnson. 1976. Site and extent of starch digestion in steers fed processed corn rations. J. Anim. Sci. 43:1088-1094.

Huntington, G. B. 1997. Starch utilization by ruminants: From basics to the bunk. J. Anim. Sci. 75:852-867.

McCullough, H. 1967. The determination of ammonia in whole blood by direct colorimetric method. Clin. Chim. Acta 17:297-304.

Mertens, D. R. 1987. Predicting intake and digestibility using mathematical models of ruminal function. J. Anim. Sci. 64:1548-1558.

Murphy, T. A., F. L. Fluharty, and S. C. Loerch. 1994. The influence of intake level and corn processing on digestibility and ruminal metabolism in steers fed all-concentrate diets. J. Anim. Sci. 72:1608-1615.

NRC. 1996. Nutrient Requirements of Beef Cattle. 7th ed. National Academy Press, Washington, DC. 
Obispo, N. E., and B. A. Dehority. 1999. Feasibility of using total purines as a marker for ruminal bacteria. J. Anim. Sci. 77:3084-3095.

Owens, F. N., D. S. Secrist, W. J. Hill, and D. R. Gill. 1997. The effect of grain source and grain processing on performance of feedlot cattle: a review. J. Anim. Sci. 75:868-879.

Raun, N. S., and W. Burroughs. 1962. Suction strainer technique in obtaining rumen fluid samples from intact lambs. J. Anim. Sci. 21:454-457.

Satter, L. D., and L. L. Slyter. 1974. Effect of ammonia concentration on rumen microbial protein production in vitro. Br. J. Nut. 32:199-208.

Shain, D. H., R. A. Stock, T. J. Klopfenstein, and D. W. Herold. 1999. The effect of forage source and particle size on finishing yearling steer performance and ruminal metabolism. J. Anim. Sci. 77:1082-1092.

Stock, R. A., M. H. Sindt. R. M. Cleale IV, and R. A. Britton. 1991. High-moisture corn utilization in finishing cattle. J. Anim. Sci. 69:1645-1656.

Streeter, M. N., S. J. Barron, D. G. Wagner, C. A. Hibberd, F. N. Owens, and F. T. McCollum. 1991. Technical note: A double L intestinal cannula for cattle. J. Anim. Sci. 69:2601-2607.
Strobel, H. J., and J. B. Russell. 1986. Effect of $\mathrm{pH}$ and energy spilling on bacterial protein synthesis by carbohydrate-limited cultures of mixed bacteria. J. Dairy Sci. 69:2941-2947.

Theurer, C. B. 1986. Grain processing effects on starch utilization by ruminants. J. Anim. Sci. 63:1649-1662.

Waldo, D. R., and H. K. Goering. 1979. Insolubility of proteins in ruminant feeds by four methods. J. Anim. Sci. 49:1560-1568.

Williams, C. H., D. J. David, and O. Iismaa. 1962. The determination of chromic oxide in faeces by atomic absorption spectrophotometry. J. Agric. Sci. 59:381-385.

Zinn, R. A. 1990. Influence of steaming time on site of digestion of flaked corn in steers. J. Anim. Sci. 68:776-781.

Zinn, R. A., C. F. Adam, and M. S. Tamayo. 1995. Interaction of feed intake level on comparative ruminal and total tract digestion of dry-rolled and steam-flaked corn. J. Anim. Sci. 73:1239-1245.

Zinn, R. A., E. G. Alvarez, M. F. Montano, A. Plascencia, and J. E. Ramirez. 1998. Influence of tempering on the feeding value of rolled corn in finishing diets for feedlot cattle. J. Anim. Sci. 76:2239-2246.

Zinn, R. A., and F. N. Owens. 1986. A rapid procedure for purine measurements and its use for estimating net ruminal protein synthesis. Can. J. Anim. Sci. 66:157-166. 